\title{
Multimedia Interactive Learning on Indonesian Language Content
}

\author{
Ni Made Ayu Christina ${ }^{1 *}$, Ni Nyoman Ganing ${ }^{2 *}$ (iD) \\ ${ }^{12}$ Pendidikan Guru Sekolah Dasar, Universitas Pendidikan Ganesha, Singaraja, Indonesia \\ *Corresponding author: christinaayu4@gmail.com
}

\begin{abstract}
Abstrak
Dampak covid-19 yang mengharuskan segala jenis kegiatan pembelajaran dilakukan secara daring. Akibatnya guru memiliki keterbatasan dalam menemukam media pembelajaran yang cocok dengan kateristik siswa dan yang cocok digunakan dalam kondisi pembelajaran daring. Tujuan dari penelitian pengembangan ini untuk mengetahui rancang bangun dan kelayakan multimedia pembelajaran interaktif. Jenis penelitian ini adalah penelitian pengembanan. Model penelitian yang digunakan yaitu model ADDIE. Subjek dari penelitian ini adalah 3 orang siswa kelas III Sekolah Dasar. Metode pengumpulan data yang digunakan yaitu metode observasi, wawancara dan angket. Uji rancangan produk dilakukan oleh beberapa ahli dan siswa yang meliput ahli materi pembelajaran, ahli desain pembelajaran, ahli media pembelajaran, dan uji coba perorangan yang terdiri dari tiga orang siswa. Bentuk analisis data yag digunakan dalam penelitian ini adalah analisis data deskriptif kuantitatif. Berdasarkan data hasil penelitian menunjukan tingkat persentase kelayakan multimedia interaktif menurut ahli materi pembelajaran $88,33 \%$, tingkat persentase kelayakan multimedia pembelajaran interaktif menurut ahli desain pembelajaran 90\%, tingkat persentase kelayakan multimedia pembelajaran interaktif menurut ahli media pembelajaran $90 \%$ dan menurut uji coba perorangan tingkat persentase kelayakan multimedia pembelajaran interaktif sebesar 96,52\% dengan kualifikasi sangat baik. Hasil dari penelitian pengembangan ini menunjukan bahwa pengembangan multimedia pembelajaran interaktif layak digunakan dalam proses pemelajaran pada muatan Bahasa Indonesia dalam apresiasi sastra untuk siswa kelas III Sekolah Dasar.
\end{abstract}

Kata kunci: Multimedia, Interaktif, Bahasa Indonesia

\section{Abstract}

The impact of covid-19, which requires all types of learning activities to be carried out online. As a result, teachers have limitations in finding learning media suitable for student characteristics and suitable for use in online learning conditions. The purpose of this development research was to determine the feasibility of designing interactive multimedia learning. This type of research is development research. The research model used is the ADDIE model. The subjects of this study were 3 grade III elementary school students. The data collection methods used were observation, interview and questionnaire methods. The product design test was carried out by several experts and students, learning material experts, learning design experts, instructional media experts, and individual trials consisting of three students. The form of data analysis used in this research was descriptive quantitative data analysis. Based on the results of the study, showed the feasibility percentage level of interactive multimedia according to learning material experts was $95 \%$, the percentage level of the feasibility of interactive learning media according to learning design experts was $90 \%$, and according to individual trials, the percentage level of the feasibility of interactive learning multimedia was $96.52 \%$ with excellent qualifications. This development research indicated that the development of interactive multimedia learning assisted was suitable for use in the learning process on Indonesian language content in literary appreciation for grade III elementary school students.

Keywords: Multimedia, Interactive Indonesian Language

\begin{tabular}{lll}
\hline History: & & Publisher: Undiksha Press \\
Received & : March 19, 2021 & Licensed: This work is licensed under \\
Revised & : March 21, 2021 & a Creative Commons Attribution 3.0 License \\
Accepted & : June 10, 2021 & CC () O) \\
Published & : July 25, 2021 & SA
\end{tabular}

\section{Introduction}

From 2019 until now, the coronavirus is being discussed in all circles in the (Chang et al., 2020; Shodiq \& Zainiyati, 2020). The emergence of Covid-19 impacts changes in the order of life in all areas of human life, not only in the health sector, which is changing, but the economy throughout the world is experiencing weakness (Athena et al., 2020; Wong et 
al., 2020; Xiong et al., 2020).The impact of covid-19 requires all types of learning activities to be carried out online (Kadafi et al., 2021; Yulia, 2020). Teachers must design an exciting lesson that can motivate students in learning even though learning is done online (Rusli et al., 2020; Setiawan \& Ari Oka, 2020). It is a challenge for teachers during this pandemic.

Changes in education and the occurrence of online learning processes are entirely through many media such as social media, Google classroom, Meet, zoom. In other words, face-to-face learning must be changed to online learning (Dong et al., 2020; Mishra et al., 2020). Online learning is one of the solutions offered in the current learning process, with online learning helping prevent the spread of Covid-19 (Abidah et al., 2020; Karasmanaki \& Tsantopoulos, 2021). Online learning makes learning more flexible where the learning process is adapted to the child's condition, is not regulated by time and can be done anywhere (Anitha Kumari et al., 2020; Kiernan, 2020).

Online learning does not always have a positive impact. Online learning also harms children who are not sensitive to technology, and the environment where they live is not supported by the internet or signals (Hanifah Salsabila et al., 2020; Hussein et al., 2020). Another impact is that online learning will make students bored because the methods or models used are the same (Jing et al., 2020; Permata \& Bhakti, 2020). Moreover, it will also cause other problems, namely addiction to smartphones or laptops. This addiction is caused because students use cellphones or other communication tools continuously, and this use is not in finding material but playing games or social media (Fajariyah et al., 2018, Rahmawati \& Latifah, 2020, Samaha \& Hawi, 2016).

Based on the results of observations made at SD No. 2 Bongkasa found similar problems. Based on the results of observations, it was found that the learning model used by the teacher in student learning was less effective, so that students felt bored in online learning. In addition, teachers also lack learning media that can facilitate students learning online. This has an impact on decreasing students' understanding of the subject matter presented by the teacher. The lack of learning media also makes students find it more challenging to understand the learning material. If this problem is left continuously, the learning objectives will not be achieved optimally.

One way that can be applied in today's educational conditions is to use interactive multimedia learning in the learning process (Indah Septiani et al., 2020; Khamparia \& Pandey, 2017). Interactive learning multimedia is a program consisting of text, images, animation, audio and video containing certain learning content to support the learning process to create exciting and interactive learning (Komalasari \& Rahmat, 2019; Majid et al., 2012). Interactive learning multimedia is a combination of several other media, including text, video, images, audio and graphics, as well as interactive delivery methods that can make a student's learning experience linked to the lives of their students (Bus et al., 2020; Dwiqi et al., 2020). Multimedia is a combination of text, images, sound, animation, and video delivered through a computer, electronic, or other digitally engineered devices (Kalyuga, 2012; Weng et al., 2018). So based on this opinion, it is concluded that interactive learning multimedia is a digital media that combines several aspects of other media into a single unit such as text, images, sound, animation, video, and interactivity. Thus, multimedia will attract student interest and student motivation in learning so that students can master the material well (Primamukti \& Farozin, 2018; Yogiyatno \& Sofyan, 2013).

This is evidenced by previous research, which states that multimedia is more effectively used in learning to improve student learning outcomes when compared to conventional learning. (Kuswanto et al., 2017; Riyadi \& Pardjono, 2014). Other research findings also state that learning multimedia can be a medium that has enormous potential in helping the learning process (Khan \& Masood, 2015; Widyatmojo \& Muhtadi, 2017). Other findings also state that learning multimedia effectively improves student learning outcomes 
(Putri \& Muhtadi, 2018). Multimedia learning is proven to be effective in increasing the achievement of students' cognitive learning outcomes. So based on some of these findings, it can be concluded that interactive learning multimedia is proven to impact student learning outcomes positively. Based on the explanation above, it can be formulated that this development research aims to develop interactive multimedia learning for third-grade students. The combined use of digital media (interactive multimedia) in the learning process will be an alternative that teachers can use in developing and innovating creative and innovative learning to improve student learning outcomes.

\section{Methods}

This development research was carried out at SD No. 2 Bongkasa. The subjects in this development research are 1 subject content expert, 1 learning design expert, 1 learning media expert, and 3 students for individual trials. This development research procedure refers to the ADDIE model, which consists of five steps: analyze, design, development, implementation, and evaluation. The research development product that will be produced is an application of Indonesian language teaching materials, material for the intrinsic elements of fairy tales for class III SD to improve students' understanding of the contents of the reading. In this development research, only up to testing the quality of subject matter experts, learning design experts, learning media experts, and individual trials.

The data collection used in this development research is the observation method, interview method and questionnaire method. The interview method used is an unstructured interview to obtain information from sources freely without any complete or written interview guidelines. Interviews were conducted to obtain data related to problems that occur in the field (Siddiq et al., 2020). The questionnaire method was carried out to measure the feasibility of the developed product obtained from subject content experts, learning design experts, learning media experts, and individual trials.

Table 1. Material Content Expert Instrument Grid

\begin{tabular}{lll}
\hline No Aspect & & \multicolumn{1}{c}{ Indicator } \\
\hline \multirow{4}{*}{ Curriculum } & 1) The suitability of the material with basic competencies \\
& 2) The suitability of the material with the indicator \\
3) The suitability of the material with the learning objectives \\
4) Material coverage \\
5) Material accuracy \\
6) Material attraction \\
7) The suitability of the material with the student's situation \\
8) The material is easy to understand \\
9) The suitability of the evaluation with the material \\
\hline
\end{tabular}

Table 2. Learning Design Expert Instrument Grid

\begin{tabular}{llll}
\hline No & Aspect & & \multicolumn{1}{c}{ Indicator } \\
\hline \multirow{3}{*}{ Goal } & 1) & Clarity of learning objectives \\
& & 2) & Consistency between objectives, materials and \\
& evaluation \\
2 & Strategy & 3) & Learning activities can motivate students \\
& & 4) & Submission of the material provides logical steps \\
\hline
\end{tabular}




\begin{tabular}{|c|c|c|}
\hline No & Aspect & Indicator \\
\hline & & 5) Give examples in the presentation \\
\hline & & 6) Provide opportunities for students to train themselves \\
\hline & & 7) Helping the application of material in life \\
\hline & & 8) Gives attention \\
\hline & Evaluation & 9) Provided exercises for understanding the concept. \\
\hline 3 & & $\begin{array}{l}\text { 10) Clarity of instructions for working on practice/test } \\
\text { questions }\end{array}$ \\
\hline
\end{tabular}

Table 3. Learning Media Expert Instrument Grid

\begin{tabular}{lll}
\hline No & Aspect & \multicolumn{1}{c}{ Indicator } \\
\hline 1 & Text & 1) Use the appropriate typeface \\
& 2) Text legibility clarity \\
2 & Picture & 3) Standard image quality or resolution \\
& 4) The use of images on media that supports learning. \\
3 & Sound and Audio & 5) Use of appropriate narrative \\
4 & 6) Clear audio usage \\
5 & Animation & 7) Appropriate music support \\
6 & Colour & 9) Colour \\
& Technical & 10) Ease of using media \\
\end{tabular}

Data analysis methods and techniques used in this development research are qualitative and quantitative descriptive analysis methods. The data obtained in the form of descriptive data that is poured through written words is produced directly by the researcher (Wulandari, 2020). This qualitative analysis method is used to process data from reviewers to be grouped so that input and suggestions from experts can be used to improve the product developed. This quantitative descriptive analysis method is used to change the questionnaire data, which is still in the form of scores, into the percentage of responses from the subjects studied. The results of quantitative data analysis are then analyzed with media eligibility criteria which are then used for a decision. Data processing uses a Likert scale ranging from 1-4 with criteria 1 (strongly disagree), 2 (disagree), 3 (agree), 4 (strongly agree). The results of the expert validation questionnaire obtained from the experts will be summed and averaged first to find out the number of respondents' answers (Sugiyono, 2018).

\section{Results and Discussion Results}

The design of interactive multimedia development in this research uses the ADDIE development model. The development of interactive multimedia passes through five stages. First, starting from the analysis stage, three things need to be analyzed, namely (1) needs analysis. It was found that: most students have low learning outcomes because the material being studied is abstract, so it is difficult to understand, and the lack of use of digital media which is interactive in the learning process. (2) environmental analysis found that there are facilities that can be used to support the learning process, such as laptops, speakers, and LCD projectors. (3) analysis of the subject matter found that the intrinsic elements of fairy tales are essential to developing engaging learning media. 
The second stage is the design stage. At this stage, the things to do are 1) selecting and determining software that will be used to create interactive multimedia, including the Articulate application. 2) Develop a flowchart to describe the flow of product development as a whole and a reference for the next stage. 3) Develop a storyboard consisting of a series of sketches describing a sequence (storyline) and proposed elements for interactive multimedia applications that combine text, images, videos, animations, and buttons. 4) Develop assessment instruments and questions and develop a learning implementation plan (RPP) that refers to the syllabus.
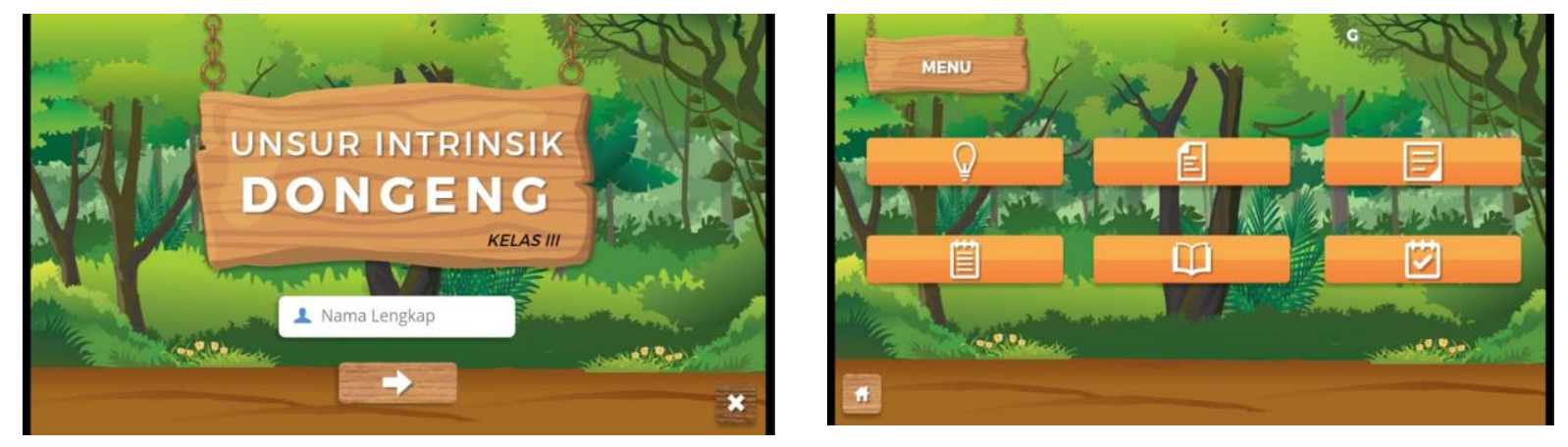

Figure 1. Developed Interactive Learning Multimedia

The fourth stage is the implementation stage. At the implementation stage, the activities carried out include: (1) product validation tests by experts, including content experts for Indonesian Class III Elementary School subjects, learning design experts and learning media experts. (2) product trials include individual trials consisting of three students. The purpose of conducting expert assessments and product trials is to determine the attractiveness and feasibility of interactive learning multimedia products that have been developed.

The last stage is the evaluation stage. The activities are carried out at this stage to evaluate the data obtained at the implementation stage (expert validity and individual trials). The evaluation carried out is formative evaluation. Formative evaluation is the process of providing and using the information to be used as a basis for decision-making to improve the quality of learning products or programs. The formative evaluation aims to assess the interactive learning multimedia products developed. Based on these stages, the development of interactive learning multimedia by applying the ADDIE model is said to be successful.

The results of the quality test of interactive learning multimedia products obtained the results of the subject content expert test of $88.33 \%$, which based on the Conversion Rate of Achievement table with a scale of 5 the validity of the subject content expert was in a good category. Furthermore, the learning design expert test obtained results of $90 \%$, namely in the very good category. Furthermore, interactive multimedia learning for third-grade elementary school students based on corrections from learning media experts obtained $90 \%$ results in the very good category. After testing the subject content experts, the learning design experts, and the learning media experts, a product trial was carried out to the third-grade students of SD No. 2 Bongkasa. This product trial was carried out with individual trials by testing interactive learning multimedia products to three third grade elementary school students: one student with high learning achievement, one student with moderate learning achievement, and one with high learning achievement. The student's learning outcomes are seen from the semester scores and the student's report cards. Individual trials conducted on 3 students got results of $96.52 \%$ in the very good category. With these data, the interactive learning multimedia 
developed is suitable for use in the learning process, especially in Indonesian language content.

\section{Discussion}

The interactive learning multimedia developed is suitable for use in the learning process, especially in Indonesian content, because it is interesting. The advantage of the developed multimedia is that it combines images that will attract students' attention. So that it makes students enthusiastic in participating in the learning process and can train students' higher-order thinking skills. This is also supported by previous research, which states that interesting learning media will attract students' attention in learning (Chen \& Li, 2011; Khamparia \& Pandey, 2017). In addition, good multimedia will make students more focused in learning (Khan \& Masood, 2015; Primamukti \& Farozin, 2018). This is because the media is everything that is used to store, carry, distribute and convey information in both verbal and visual forms. The learning process is basically a communication process, so the media used in the learning process is called learning media (Maharani, 2015; Mustaqim, 2016). Learning media also functions to stimulate thoughts, attention, feelings, and the progress of students' learning processes (Nur Jannah, 2020; Prasetyo et al., 2020).

The benefits of learning media for teachers and students are to improve the learning process, make learning more authentic and permanent, save teacher time that might be wasted in delivering presentations orally and explaining lesson content, and supporting student participation in learning activities (Marnita \& Ernawati, 2017; Qistina et al., 2019). Instructional media make learning accessible to a broader audience and help teachers and students overcome physical difficulties in teaching and learning (Gunawam et al., 2015; Heo \& Toomey, 2020). Multimedia is a combination of various media in the format of the text, graphics, images (vector or bitmap), sound, animation, and video that can be used as a means of stimulus to train skills and competencies (Fauyan, 2019). Learning multimedia helps students remember and understand information/lesson content achieved by utilizing the visual aspects of the media (Abdulrahaman et al., 2020; Lauc et al., 2020).

The findings of previous research stated that learning multimedia can be used in learning because it creates a pleasant learning atmosphere (Laksana et al., 2019; Rubini et al., 2018). Other research findings also state that learning multimedia can facilitate students learning to improve student learning (Lee \& Osman, 2012; R. Wulandari et al., 2017). So that this multimedia is effectively used in learning, this research implies that teachers can use the learning multimedia developed to help students in online learning.

\section{Conclusion}

The Interactive Learning Multimedia product that was developed got excellent qualifications based on the assessments of experts and students. So it can be concluded that the Multimedia Interactive Learning Material Elements of Intrinsic Fairy tales is very feasible to learn Indonesian in Class III Elementary School in the online and offline learning process.

\section{References}

Abdulrahaman, M. D., Faruk, N., Oloyede, A. A., Surajudeen-bakinde, N. T., \& Olawoyin, L. A. (2020). Multimedia tools in the teaching and learning processes: A systematic review. Heliyon, 6(October), e05312. https://doi.org/10.1016/j.heliyon.2020.e05312

Abidah, A., Hidaayatullaah, H. N., Simamora, R. M., Fehabutar, D., \& Mutakinati, L. (2020). The Impact of Covid-19 to Indonesian Education and Its Relation to the Philosophy of "Merdeka Belajar." Studies in Philosophy of Science and Education, 1(1), 38-49. https://doi.org/10.46627/sipose.v1i1.9 
Anitha Kumari, T., Hemalatha, C. H., Subhani Ali, M., \& Naresh, R. (2020). Survey on impact and learning's of the online courses on the present era. Procedia Computer Science, 172, 82-91. https://doi.org/10.1016/j.procs.2020.05.167

Athena, A., Laelasari, E., \& Puspita, T. (2020). Pelaksanaan Disinfeksi Dalam Pencegahan Penularan Covid-19 Dan Potensi Risiko Terhadap Kesehatan Di Indonesia. Jurnal Ekologi Kesehatan, 19(1), 1-20. https://doi.org/10.22435/jek.v19i1.3146

Bus, A. G., Neuman, S. B., \& Roskos, K. (2020). Screens, Apps, and Digital Books for Young Children: The Promise of Multimedia. AERA Open, 6(1), 233285842090149. https://doi.org/10.1177/2332858420901494

Chang, T. Y., Hong, G., Paganelli, C., Phantumvanit, P., Chang, W. J., Shieh, Y. S., \& Hsu, M. L. (2020). Innovation of dental education during COVID-19 pandemic. Journal of Dental Sciences, 155. https://doi.org/10.1016/j.jds.2020.07.011

Chen, E., \& Li, Z. (2011). On the application of multimedia technology in foreign language teaching and learning in China's colleges: Challenges, problems and implications. 2011 International Conference on Multimedia Technology, ICMT 2011, 595-597. https://doi.org/10.1109/ICMT.2011.6001903

Dong, C., Cao, S., \& Li, H. (2020). Young children's online learning during COVID-19 pandemic: Chinese parents' beliefs and attitudes. Children and Youth Services Review, 118(June), 105440. https://doi.org/10.1016/j.childyouth.2020.105440

Dwiqi, G. C. S., Sudatha, I. G. W., \& Sukmana, A. I. W. I. Y. (2020). Pengembangan Multimedia Pembelajaran Interaktif Mata Pelajaran IPA Untuk Siswa SD Kelas V. Jurnal Edutech Undiksha, 8(2), 33. https://doi.org/10.23887/jeu.v8i2.28934

Fajariyah, S. N., Suryawan, A., \& Atika, A. (2018). Dampak Penggunaan Gawai Terhadap $\begin{array}{lllll}\text { Perkembangan } & \text { Anak. Sari } & \text { Pediatri, } & \text { 20(2), }\end{array}$ https://doi.org/10.14238/sp20.2.2018.101-5

Fauyan, M. (2019). Developing Interactive Multimedia Through Ispring on Indonesian Learning with the Insight Islamic Values in Madrasah Ibtidaiyah. Al Ibtida: Journal Pendidikan Guru MI, 6(2). https://doi.org/10.24235/al.ibtida.snj.v6i2.4173

Gunawam, G., Harjono, A., \& Sutrio, S. (2015). Multimedia Interaktif dalam Pembelajaran Konsep Listrik Bagi Calon Guru. Jurnal Pendidikan Fisika Dan Teknologi, 1(1), 9-14. https://doi.org/10.29303/jpft.v1i1.230

Hanifah Salsabila, U., Irna Sari, L., Haibati Lathif, K., Puji Lestari, A., \& Ayuning, A. (2020). Peran Teknologi Dalam Pembelajaran Di Masa Pandemi Covid-19. AlMutharahah: Jurnal Penelitian Dan Kajian Sosial Keagamaan, 17(2), 188-198. https://doi.org/10.46781/al-mutharahah.v17i2.138

Heo, M., \& Toomey, N. (2020). Learning with multimedia: The effects of gender, type of multimedia learning resources, and spatial ability. Computers and Education, 146, 103747. https://doi.org/10.1016/j.compedu.2019.103747

Hussein, E., Daoud, S., Alrabaiah, H., \& Badawi, R. (2020). Exploring undergraduate students' attitudes towards emergency online learning during COVID-19: A case from the UAE. Children and Youth Services Review, 119(10), 105699. https://doi.org/10.1016/j.childyouth.2020.105699

Indah Septiani, A. nisa N. S., Septiani, I., Rejekiningsih, T., Triyanto, \& Rusnaini. (2020). Development of interactive multimedia learning courseware to strengthen students' character. European Journal of Educational Research, 9(3), 1267-1279. https://doi.org/10.12973/eu-jer.9.3.1267

Jing, S., Tang, Y., Liu, X., \& Gong, X. (2020). A Learner Model Integrating Cognitive and Metacognitive and Its Application on Scratch Programming Projects. IFACPapersOnLine, 53(5), 644-649. https://doi.org/10.1016/j.ifacol.2021.04.154

Kadafi, A., Alfaiz, A., Ramli, M., Asri, D. N., \& Finayanti, J. (2021). The impact of islamic 
counseling intervention towards students' mindfulness and anxiety during the covid-19 pandemic. Islamic Guidance and Counseling Journal, 4(1), 55-66. https://doi.org/10.25217/igcj.v4i1.1018

Kalyuga, S. (2012). Interactive distance education: A cognitive load perspective. Journal of Computing in Higher Education. https://doi.org/10.1007/s12528-012-9060-4

Karasmanaki, E., \& Tsantopoulos, G. (2021). Impacts of social distancing during COVID-19 pandemic on the daily life of forestry students. Children and Youth Services Review, 120(December 2020), 105781. https://doi.org/10.1016/j.childyouth.2020.105781

Khamparia, A., \& Pandey, B. (2017). Impact of interactive multimedia in E-learning technologies: Role of multimedia in E-learning. Enhancing Academic Research With Knowledge Management Principles, April, 199-227. https://doi.org/10.4018/978-15225-2489-2.ch007

Khan, F. M. A., \& Masood, M. (2015). The Effectiveness of an Interactive Multimedia Courseware with Cooperative Mastery Approach in Enhancing Higher Order Thinking Skills in Learning Cellular Respiration. Procedia - Social and Behavioral Sciences, 176, 977-984. https://doi.org/10.1016/j.sbspro.2015.01.567

Kiernan, J. E. (2020). Pedagogical commentary: Teaching through a pandemic. Social $\begin{array}{lllll}\text { Sciences } \& \text { Humanities } & \text { Open, } & 2(1), & \end{array}$ https://doi.org/10.1016/j.ssaho.2020.100071

Komalasari, K., \& Rahmat, R. (2019). Living Values Based Interactive Multimedia in Civic Education Learning. International Journal of Instruction, 12(1), 113-126. https://doi.org/10.29333/iji.2019.1218a

Kuswanto, J., Walusfa, Y., Artikel, S., Korespondensi, A., Ratu Penghulu No, J., Sari, K., Baru, T., Raja Tim, B., Ogan Komering Ulu, K., \& Selatan, S. (2017). Pengembangan Multimedia Pembelajaran pada Mata Pelajaran Teknologi Informasi dan Komunikasi Kelas VIII. Innovative Journal of Curriculum and Educational Technology IJCET, 6(2), 58-64. https://doi.org/10.15294/ijcet.v6i2.19335

Laksana, D. N. L., Dasna, I. W., \& Degeng, I. N. S. (2019). The effects of inquiry-based learning and learning styles on primary school students' conceptual understanding in multimedia learning environment. Journal of Baltic Science Education, 1(1). https://doi.org/10.33225/jbse/19.18.51

Lauc, T., Jagodić, G. K., \& Bistrović, J. (2020). Effects of Multimedia Instructional Message on Motivation and Academic Performance of Elementary School Students in Croatia. International Journal of Instruction, 13(4), 491-508. https://doi.org/10.29333/iji.2020.13431a

Lee, T. T., \& Osman, K. (2012). Interactive Multimedia Module in the Learning of Electrochemistry: Effects on Students' Understanding and Motivation. Procedia - Social and Behavioral Sciences, 46. https://doi.org/10.1016/j.sbspro.2012.05.295

Maharani, Y. S. (2015). Efektivitas Multimedia Pembelajaran Interaktif Berbasis Kurikulum 2013. Indonesian Journal of Curriculum and Educational Technology Studies, 3(1), 3140. https://doi.org/10.15294/ijcets.v3i1.8683

Majid, M. S. Z. B. A., Ali, M. M. B. A., Rahim, A. A. B. A., \& Khamis, N. Y. B. (2012). The Development of Technical English Multimedia Interactive Module to Enhance Student Centered Learning (SCL). Procedia - Social and Behavioral Sciences, 67, 345-348. https://doi.org/10.1016/j.sbspro.2012.11.337

Marnita, \& Ernawati. (2017). The Use of Interactive Multimedia (Macromedia Flash) to Increase Creative Thinking Ability of Students in Basic Physics Subject. Jurnal Pendidikan Fisika Indonesia, 13(2), 71-78. https://doi.org/10.15294/jpfi.v13i2.10152

Mishra, L., Gupta, T., \& Shree, A. (2020). Online teaching-learning in higher education during lockdown period of COVID-19 pandemic. International Journal of Educational 
Research Open, 1, 100012. https://doi.org/10.1016/j.ijedro.2020.100012

Mustaqim, I. (2016). Multimedia services on top of M3 Smart Spaces. Jurnal Pendidikan Teknologi Dan Kejuruan, 13(2), 174. https://doi.org/10.23887/jptk-undiksha.v13i2.8525

Nur Jannah, I. (2020). Efektivitas Penggunaan Multimedia dalam Pembelajaran IPA di SD. Jurnal Ilmiah Sekolah Dasar, 4(1), 54. https://doi.org/10.23887/jisd.v4i1.24135

Permata, A., \& Bhakti, Y. B. (2020). Keefektifan Virtual Class dengan Google Classroom dalam Pembelajaran Fisika Dimasa Pandemi Covid-19. JIPFRI (Jurnal Inovasi Pendidikan Fisika Dan Riset Ilmiah), 4(1), 27-33. https://doi.org/10.30599/jipfri.v4i1.669

Prasetyo, G., Hidayatullah, M. F., Akhyar, M., Wiranto, \& Perdana, R. (2020). Strengthening Students' Character Through Multimedia Learning In Primary Schools Education: Systematic LiteraturPrasetyo, G., Hidayatullah, M. F., Akhyar, M., Wiranto, \& Perdana, R. (2020). Strengthening Students' Character Through Multimedia Learning In . Humanities \& Social Sciences Reviews, 8(3), 268-277. https://doi.org/10.18510/hssr.2020.8328

Primamukti, A. D., \& Farozin, M. (2018). Utilization of interactive multimedia to improve learning interest and learning achievement of child. Jurnal Prima Edukasia, 6(2), 111117. https://doi.org/10.21831/jpe.v6i2.19183

Putri, D. P. E., \& Muhtadi, A. (2018). Pengembangan multimedia pembelajaran interaktif kimia berbasis android menggunakan prinsip mayer pada materi laju reaksi. Jurnal Inovasi Teknologi Pendidikan, 5(1), 38-47. https://doi.org/10.21831/jitp.v5i1.13752

Qistina, M., Alpusari, M., Noviana, E., \& Hermita, N. (2019). Pengembangan Multimedia Interaktif Mata Pelajaran Ipa Kelas Ivc Sd Negeri 034 Taraibangun Kabupaten Kampar. Primary: Jurnal Pendidikan Guru Sekolah Dasar, 8(2), 148. https://doi.org/10.33578/jpfkip.v8i2.7649

Rahmawati, M., \& Latifah, M. (2020). Penggunaan Gawai, Interaksi Ibu-Anak, Dan Perkembangan Sosial-Emosional Anak Prasekolah. Jurnal Ilmu Kel. Dan Konseling, 13(1), 75-86. https://doi.org/10.24156/jikk.2020.13.1.75

Riyadi, S., \& Pardjono, P. (2014). Pengembangan Multimedia Pembelajaran Matematika Berbasis Komputer Untuk Kelas Viii Smp. Jurnal Inovasi Teknologi Pendidikan, 1(2), 165-177. https://doi.org/10.21831/tp.v1i2.2527

Rubini, B., Permanasari, A., \& Yuningsih, W. (2018). Learning Multimedia Based on Science Literacy on the Lightning Theme. Journal of Science Learning and Research, 4(2), 89-104. https://doi.org/10.30870/jppi.v4i2.3926

Rusli, R., Rahman, A., \& Abdullah, H. (2020). Student perception data on online learning using heutagogy approach in the Faculty of Mathematics and Natural Sciences of Universitas Negeri Makassar, Indonesia. Data in Brief, 29, 105152. https://doi.org/10.1016/j.dib.2020.105152

Samaha, M., \& Hawi, N. S. (2016). Computers in Human Behavior Relationships among smartphone addiction, stress, academic performance, and satisfaction with life. Computers in Human Behavior, 57, 321-325. https://doi.org/10.1016/j.chb.2015.12.045

Setiawan, I. M. D., \& Ari Oka, I. D. G. (2020). The Use of Audio-Visual Assisted Google Classroom for Mathematics Course. Journal of Education Technology, 4(3), 244. https://doi.org/10.23887/jet.v4i3.28529

Shodiq, I. J., \& Zainiyati, H. S. (2020). Pemanfaatan Media Pembelajaran E-Learning Menggunakan Whastsapp Sebagai Solusi Ditengah Penyebaran Covid-19 Di Mi Nurulhuda Jelu. Al-Insyiroh: Jurnal Studi Keislaman, 6(2), 144-159. https://doi.org/10.35309/alinsyiroh.v6i2.3946

Siddiq, Y. I., Sudarma, I. K., \& Simamora, A. H. (2020). Pengembangan Animasi Dua Dimensi pada Pembelajaran Tematik untuk Siswa Kelas III Sekolah Dasar. Jurnal 
Edutech Undiksha, 8(2), 49-63. https://doi.org/10.23887/jeu.v8i2.28928

Suartama, I. K. (2016). Materi 4 Evaluasi dan Kriteria Kualitas Multimedia Pembeajaran

Oleh: I Kadek Suartama Jurusan Teknologi Pendidikan Universitas Pendidikan

Ganesha Tahun 2016. September, 1-18.

Sugiyono. (2018). Metode penelitian kuatintatif, kualitatif dan R \& D. In Bandung: Alfabeta.

Weng, C., Otanga, S., Weng, A., \& Cox, J. (2018). Effects of interactivity in E-textbooks on 7th graders science learning and cognitive load. Computers \& Education, 120, 172-184. https://doi.org/10.1016/j.compedu.2018.02.008

Widyatmojo, G., \& Muhtadi, A. (2017). Pengembangan multimedia pembelajaran interaktif berbentuk game untuk menstimulasi aspek kognitif dan bahasa. Jurnal Inovasi Teknologi Pendidikan, 4(1), 38. https://doi.org/10.21831/jitp.v4i1.10194

Wong, G. L. H., Wong, V. W. S., Thompson, A., Jia, J., Hou, J., Lesmana, C. R. A., Susilo, A., Tanaka, Y., Chan, W. K., Gane, E., Ong-Go, A. K., Lim, S. G., Ahn, S. H., Yu, M. L., Piratvisuth, T., \& Chan, H. L. Y. (2020). Management of patients with liver derangement during the COVID-19 pandemic: an Asia-Pacific position statement. The Lancet Gastroenterology and Hepatology, 5(8), 776-787. https://doi.org/10.1016/S2468-1253(20)30190-4

Wulandari, A. (2020). Implementation of the 2013 Curriculum Based on a Scientific Approach (Case Study at SD Cluster II Kintamani). International Journal of Elementary Education, 4(3), 422. https://doi.org/10.23887/ijee.v4i3.28172

Wulandari, R., Susilo, H., \& Kuswandi, D. (2017). Penggunaan Multimedia Interaktif Bermuatan Game Edukasi untuk Meningkatkan Aktivitas dan Hasil Belajar Siswa Sekolah Dasar. Jurnal Pendidikan: Teori, Penelitian Dan Pengembangan, 2(8), 10241029. http://dx.doi.org/10.17977/jptpp.v2i8.9759.

Xiong, W., Mok, K. H., Ke, G., Oi, J., \& Cheung, W. (2020). Impact of COVID-19 Pandemic on International Higher Education and Student Mobility: Student Perspectives from Mainland China and Hong Kong. Centre for Global Higher Education, 105(August 2020), 101718. https://doi.org/10.1016/j.ijer.2020.101718

Yogiyatno, W., \& Sofyan, H. (2013). Pengembangan multimedia interaktif kompetensi dasar mengoperasikan software basis data untuk SMK Negeri 1 Seyegan. Jurnal Pendidikan Vokasi, 3(3), 391-404. https://doi.org/10.21831/jpv.v3i3.1851

Yulia. (2020). Online Learning to Prevent the Spread of Pandemic Corona Virus in Indonesia. ETERNAL (English Teaching Journal), 11(1). https://doi.org/10.26877/eternal.v11i1.6068 